\title{
Antibacterial Activity of Silver Nanoparticles Synthesized by Sidr (Ziziphus spina- Christi) Leaf Extract against Pathogenic Bacteria
}

\author{
Masoud E. A ${ }^{1 *}$, A.Al-Hajry $\mathbf{M}^{2}$ and Al-Marrani. $A^{3}$ \\ ${ }^{1}$ Department of Applied Medical Sciences, Community College,Najran University, Saudi Arabia \\ ${ }^{2}$ Advanced Materials and Nanoscale Research Laboratory, Najran University, Saudi Arabia \\ ${ }^{3}$ Department of Hadeath, Sharea College, Najran University, Saudi Arabia \\ *Corresponding author
}

\begin{abstract}
A B S T R A C T
Keywords

Silver

nanoparticles;

Antibacterial

activity;

Ziziphus spina-

Christi;

UV-Vis

Spectrophotometer,

FE-SEM, XRD.

\section{Article Info}

Accepted:

15 March 2016

Available Online:

10 April 2016

This study aimed to synthesize silver nanoparticles using aqueous sidr leaves extract and to evaluate the antibacterial efficacy of sidr leaves extract, silver nitrate and silver nanoparticles against gram positive (Staphylococcus aureus and Streptococcus pyogenes) and gram-negative (Escherichia coli, Pseudomonas aeruginosa and Klebsiella pneumoniae) bacteria using agar well diffusion technique. The synthesis of silver nanoparticles using sidr leaves extract was successfully carried out. UV-Vis Spectrophotometer, Field Emission Scanning Electron Microscope (FE-SEM) and X-ray diffraction (XRD) analysis confirmed synthesis of silver nanoparticles. The UV-visible spectra showed that the absorption peak was existed at 442nm. FE-SEM analysis demonstrated that the synthesized AgNPs were ellipsoidal and spherical in shape, loosely bound with no agglomeration and had an average size of 30-70 nm. The XRD results indicated that the synthesized product showed typical crystalline peaks for the face-centered cubic metallic Ag. The results showed that the water sidr leaves extract at the concentration used for synthesis of silver nanoparticles $(7.5 \mathrm{mg} / \mathrm{ml})$ did not exhibit any growth inhibitory effect against the tested microorganisms. Silver nanoparticles and silver nitrate inhibited the growth of all gram positive and gram-negative bacteria nevertheless; Silver nanoparticles had superior antibacterial activity than silver nitrate. $K$. pneumoniae was the most sensitive organism to silver nanoparticles with IZD $15.67 \pm 0.33$. The present study showed that AgNPs might be a promising antimicrobial agent for successful treatment of bacterial infection and limitation of drug resistance.
\end{abstract}

\section{Introduction}

The field of nanotechnology is one of the most active researches nowadays in modern material science and technology. Nanoparticles are fundamental building blocks of nanotechnology.
The most important and distinct property of nanoparticles is their large surface area to volume ratio (Leela and Vivekanandan, 2008). There is a commercial demand for nanoparticles due to their wide applicability 
in various areas such as electronics, catalysis, chemistry, energy and medicine (Veerasamy et al., 2011). An eco-friendly green mediated synthesis of inorganic nanoparticle is a fast growing research in nanotechnology (Sathya et al., 2012). The most important application of silver and AgNPs is in medical industry such as topical ointments to prevent infection against burn and open wounds (Muhammad et al., 2012). The biosynthesis method employing plant extracts have drawn attention as a simple and viable alternative to chemical procedures and physical methods. Bio reduction of silver ions yields metal nanoparticles using living plants (Savithramma et al., 2011). Bacterial resistance develop and spread and the effectiveness of the antibiotics is diminished. Antibiotic resistance creates a challenge for developing new drugs to overcome infections (Lia et al., 2015).

This type of bacterial resistance to the antimicrobial agents poses a very serious threat to public health, and for all kinds of antibiotics, including the major last-resort drugs, as the frequencies of resistance are increasing worldwide (Levy and Marshall, 2004; Mandal et al., 2009). Discovery of new antibacterial agent represents a revolution in the world of antimicrobials to face increase of bacterial resistance to conventional antibiotics (Gouda and Masoud, 2014).

Plants are considered an important potential source of new antibacterial agents. Zizyphusspina-christi is a scientific name of a plant where its common name is Sidr, Nebeq or Nabg in Saudi Arabia. The genus Zizyphus belong to the family Rhamnaceae. The plant is mentioned in the holy Quran many times and very much used in Arab countries. Sidr plants are widely distributed in Saudi Arabia. All parts of this plant are used by local Arab people to help maintain a healthy lifestyle. Zizyphusspina-christi has been used in folk medicine as a demulcent, depurative, anodyne, emollient, stomachic, for toothaches, astringent and as a mouth wash (Nazif, 2002). The fruits are edible and nutritive, leaves used for chest and stomach problems, bleeding of uterus and for hair and skin care. In different folk medicine the plant is used for scorpion stings, cough, constipation, pneumonia, headache, dysentery, intestinal worms, fever, eye diseases and inflammations of throat and pharynx. Different extracts and fractions of the leaves, fruits and seeds of Zizyphus showed antiviral, antifungal and antibacterial activities (Shaht et al., 2001). Silvernano particles (AgNPs) have become an attractive alternative to antibiotics due to their broad-spectrum antimicrobial activity. Synthesized silver nanoparticles from plant species are toxic to multi drug resistant microorganisms. It shows that they have great potential in biomedical applications. More over the silver nanoparticles enhance the therapeutic efficacy and strengthen the medical values of herbal plants (Savithramma et al., 2011).The aim of this study was to synthesize silver nanoparticles using aqueous sidr leaves extract and to evaluate the antibacterial efficacy of sidr leaves extract, silver nitrate and silver nanoparticles against pathogenic bacteria.

\section{Materials and Methods}

\section{Collection of Sidr Leaves}

Healthy leaves of Sidr (ZiziphusspinaChristi) were collected from sidr trees distributed in Najran region (Figure 1a, 1b), Saudi Arabia. Najran is a region of Saudi Arabia, located in the south of the country along the border with Yemen. It has an area of $119,000 \mathrm{~km}^{2}$. Its capital is Najran. 


\section{Preparation of Sidr Leaves Extract}

Collected leaves were washed thoroughly 4 times in running tap water followed by distilled water. Leaves were shade dried at room temperature for 10 days, then powdered using kitchen blender. $750 \mathrm{mg}$ ofsidr leaves powder was weighed and mixed in $100 \mathrm{ml}$ of distilled water and the mixture was boiled for 5 minutes then filtered through Whattman filter paper No.1.The filtrate was collected and stored at $4^{\circ} \mathrm{C}$ for further use (Figure 2a). The plant extract was prepared atMicrobiology laboratory, Community College, Najran University.

\section{Preparation of $1 \mathrm{mMAgNO}_{3}$ Solutions}

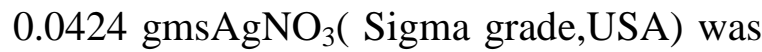
dissolved in $250 \mathrm{ml}$ of Milli Q water and stored in an amber colored bottle to avoid auto oxidation of silver ions (Figure 2b).

\section{Synthesis of Silver Nanoparticles}

For synthesis silver nanoparticles, $10 \mathrm{ml}$ of sidr leaves extract was added to $90 \mathrm{ml}$ of 1 $\mathrm{mMAgNO}_{3}$ solution in a $250 \mathrm{ml}$ flask with vigorous shaking for the bioreduction of $\mathrm{Ag}+$ ions. The color change indicated preliminary confirmation for the formation of silver nanoparticles (Figure 2C).The Mixture was incubated in the dark at $37^{\circ} \mathrm{C}$ for 24 hours.

\section{Characterization and Confirmation of Silver Nanoparticles Synthesis}

The characterization and confirmation of silver nanoparticles synthesis was conducted at Advanced Materials and Nano scale Research Laboratory, Najran University, Saudi Arabia.

\section{UV-Vis Spectrophotometer}

UV-vis spectral analysis was conducted using a Perkin Elmer-Lambda 950 - UVvisiblespectrometer. UV-vis spectra of $\mathrm{AgNPs}$ and $\mathrm{Ag}$ ions were recorded in the range from 200 to $800 \mathrm{~nm}$.

\section{FE-SEM Analysis of Silver Nanoparticles}

Field Emission Scanning Electron Microscope, FE-SEM (JSM-7600F-JEOL) was usedto examine the morphology of synthesized silver nanoparticles.

\section{X-ray Diffraction}

XRD patterns were taken on a Bruker AXS D4 Endeavour $\mathrm{X}$ diffractometerusing $\mathrm{Cu}$ $\mathrm{K} \alpha_{1 / 2}, \lambda \alpha_{1}=154.060 \mathrm{pm}, \lambda \alpha_{2}=154.439 \mathrm{pm}$ radiation.

\section{Source of Bacterial Isolates and Culture Media}

The bacterial isolates used in this study were Staphylococcus aureus, Streptococcus pyogenes, Escherichia coli, Pseudomonas aeruginosa and Klebsiella pneumoniae. All the isolates were obtained from the Microbiology laboratory, King Khalid Hospital, Najran region, Saudi Arabia. The organisms were identified by an automated system (Micro Scan Walkaway, Siemens) and the results were confirmed (Koneman et al., 1992).The isolates were subcultured on appropriate agar plates 24 hours before any antibacterial test. Brain Heart Infusion broth (Oxoid, England), Mueller Hintonagar (Oxoid, England) and Nutrient agar media (Oxoid, England) were used in this investigation.

\section{Antibacterial Activity}

The growth inhibitory effect of sidr leavesextract, $1 \mathrm{mM}$ silver nitrate and synthesized silver nanoparticles was determined by the agar well diffusion method according to NCCLS (1993). The 
bacterial cultures were grown in Brain Heart Infusion broth for 4 hours at $37{ }^{\circ} \mathrm{C}$. Each microorganism, at a concentration of $1.5 \times$ $10^{6}$ cells $/ \mathrm{ml}$ (matched to $0.5 \mathrm{McFarland}$ turbidity standards) was streaked over the surface of Mueller Hinton agar plates by using swab. The inoculum was allowed to dry at room temperature, the medium was punched with six millimeters diameter wells. The growth inhibitory effect was checked by introducing $50 \mu \mathrm{l}$ of sidr leaves extract, 1 $\mathrm{mM}$ silver nitrate and synthesized silver nanoparticles into the wells and allowed to diffuse at room temperature for 20 minutes. The plates were incubated at $37{ }^{\circ} \mathrm{C}$ for 24 hours and inhibition zones diameter (IZD) were measured $(\mathrm{mm})$. Tests were done in triplicate and the growth inhibitory effect was recorded. Amikacin (Oxoid) antibiotic disc $(30 \mu \mathrm{g})$ was used as a positive control.

\section{Statistical Analysis}

The results of antibacterial activity for Sidr leaves extract, silver nitrate and silver nanoparticles against tested bacteriawere expressed as means \pm S.E. (Standard Error) and differences between means were analyzed statistically by analysis of variance (ANOVA) according to Tukey's HSD test via Statistical Package for the Social Sciences(SPSS) 15.0 software package in Microsoft Windows 7.0 operating system. Differences are considered significant when $\mathrm{p} \leq 0.05$.

\section{Results and Discussion}

\section{Synthesis of Silver Nanoparticles using Sidr Leaf Extract}

The synthesis of silver nanoparticles is an advanced technique in modern nano biotechnology and is evolving as an important branch of nanotechnology (Koyyati et al., 2014).In this study, the synthesis of silver nanoparticles using sidr leaves extract was successfully carried out, as the characteristic reddish brown color of the mixture was observed within 3 minutes after addition of $10 \mathrm{ml}$ of water sidr leaves extract into $90 \mathrm{ml}$ of $1 \mathrm{mM}$ silver nitrate with vigorous shaking (Figure2c). Formation of reddish brown coloration indicated the ability of sidr leaves extract for biochemical reduction and capping of silver nitrate and synthesis of silver nanoparticles due to excitation of surface plasmonvibrations. The reduction rate was increased by incubation the mixture at $37{ }^{\circ} \mathrm{C}$ for 24 hours. These findings were supported by the results previously recorded (Lalitha et al., 2013; Reiad et al., 2013; Satyavani et al., 2013; Muniyappanand Nagarajan, 2014; Sundararajan and Kumari, 2014; Ibrahim, 2015).

\section{UV-Vis Spectrophotometer Analysis}

The reduction process was further monitored via the measurement of the UV-visible spectra. Figure 3 shows the UV-visible absorption spectra recorded for Ag ions and AgNPs. A broad surface plasmon resonance (SPR) absorption peak for silver nanoparticles was noticed at wavelength around $442 \mathrm{~nm}$, owning to the dipole resonance of conducting electrons on the surface of AgNPs. The inset UV-vis spectrum was related to the Ag ions before the bio-reduction event, in which an absorption band appeared at $290 \mathrm{~nm}$. The appearance of the above SPR peak at 420 $\mathrm{nm}$, along with the absence of $290 \mathrm{~nm}$ absorption band is an indication of the successful synthesis of AgNPs under the current experimental conditions. Such a characteristic SPR peak for AgNPs has been reported to predominantly appear in the range of 400-500 nm (Kaur et al., 2012; Venugopal and Mitra, 2013; Judita et al., 2014; Salem et al., 2014; Ajitha et al., 2015). Additionally, a similar absorption peak for AgNPs synthesized using a coffee 
extract is recently reported (Dhand et al., 2016).

\section{FE-SEM Analysis of Silver Nanoparticles}

Field Emission Scanning Electron Microscope as a powerful tool used for investigation the distribution and morphology of the synthesized silver nanoparticles. Fig.4 shows the FE-SEM image of synthesized AgNPs. The shapes of AgNPs proved to be ellipsoidal and spherical. Owning to the sonication treatment applied during the separation of AgNPs from the liquor, the SEM micrograph revealed loosely bound particles with almost no agglomerates. SEM analysis demonstrated that the particle sizes located in the range of $30-70 \mathrm{~nm}$. Similar phenomenon has been reported in previous studies (Sukirtha et al., 2011; Jeeva et al., 2014; Koyyati et al., 2014).

\section{X-ray Diffraction}

The XRD pattern was depicted in Fig.5 for the as-synthesized AgNPs. The results indicated that the synthesized product showed typical crystalline peaks for the face-centered cubic metallic Ag (JCPDS no.04-0783); at $2 \theta=38.28,44.48,64.68$ and 77.22 corresponding, respectively to (111), (200), (220) and (311) facets of Ag. The appearance of the Ag-related peaks in the diffraction pattern clearly indicated the formation of crystalline AgNPs. Unidentified peaks were showed in the XRD studies. Appearance of these peaks may be attributed to phytochemical compounds present in sidr leaves extract. The present results were consistent with the findings previously observed by (Rajakumar and Abdul Rahuman,2011; Bhuvaneswaria et al., 2014; Latha et al., 2015; Remya et al., 2015).

\section{Antibacterial Activity}

The growth inhibitory effect of sidr leaves extract, $1 \mathrm{mM}$ silver nitrate and silver nanoparticles against bacteria were presented in Table1.The results showed that thewater extract of sidr leaves at the concentration used for synthesis of silver nanoparticles $(7.5 \mathrm{mg} / \mathrm{ml})$ did not exhibit any growth inhibitory effect against all the tested microorganisms with IZDs $00.00 \pm 0.00$. These results may be attributed to use a low concentration of aqueous sidr leaves extract. El-Kamali and Mahjoub (2009) stated that aqueous extract of Ziziphus spina-christi at a concentration of $100 \mathrm{mg} / \mathrm{ml}$ had antibacterial activity against selected bacteria. $1 \mathrm{mMAgNO}_{3}$ solution inhibited the growth of tested bacteria and Strept. Pyogenes was the most sensitive organism with IZD $12.67 \pm 0.33$. This result was consistent with the results previously cited by (Najah, 2012).

Table.1 The Growth Inhibitory Effect of Sidr Leaves Extract, Silver Nitrate, Silver Nanoparticles and Amikacin (30 $\mu \mathrm{g})$ against Bacteria (all values in $\mathrm{mm}$ )

\begin{tabular}{llcccc}
\hline \multicolumn{1}{c}{ Bacteria } & Sidr extract & $\mathrm{AgNO}_{3}$ & AgNPs & Amikacin $(30 \mu \mathrm{g})$ \\
\hline 1 & S.aureus & $00.00 \pm 0.00$ & $11.00 \pm 0.00^{\mathrm{ab}}$ & $14.00 \pm 0.00^{\mathrm{ab}}$ & $24.00 \pm 0.00$ \\
2 & Strept. Pyogenes & $00.00 \pm 0.00$ & $12.67 \pm 0.33^{\mathrm{c}}$ & $14.33 \pm 0.33^{\mathrm{b}}$ & $29.00 \pm 0.00$ \\
3 & E. coli & $00.00 \pm 0.00$ & $11.33 \pm 0.33^{\mathrm{ab}}$ & $13.00 \pm 0.00^{\mathrm{a}}$ & $23.00 \pm 0.00$ \\
4 & P. aeruginosa & $00.00 \pm 0.00$ & $10.33 \pm 0.33^{\mathrm{a}}$ & $13.33 \pm 0.33^{\mathrm{ab}}$ & $23.00 \pm 0.00$ \\
5 & K. pneumonia & $00.00 \pm 0.00$ & $12.00 \pm 0.00^{\mathrm{bc}}$ & $15.67 \pm 0.33^{\mathrm{c}}$ & $22.00 \pm 0.00$ \\
\hline$F$ - value & - & 12.167 & 16.167 & - \\
\hline
\end{tabular}

-Values are the mean of three replicates \pm S.E. - In the same column, means followed by the same letters are not significantly different $(\mathrm{p} \leq 0.05)$ as analyzed by Tukey's HSD test. F-value is significant at $\mathrm{p} \leq 0.001$ 

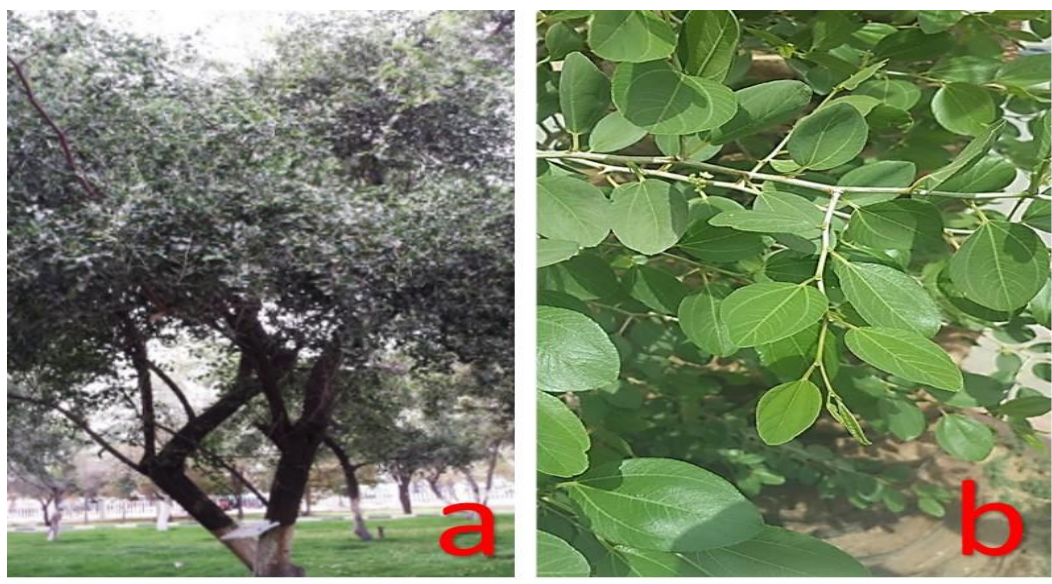

Fig. 1: (a) sidr tree; (b) sidr leaves

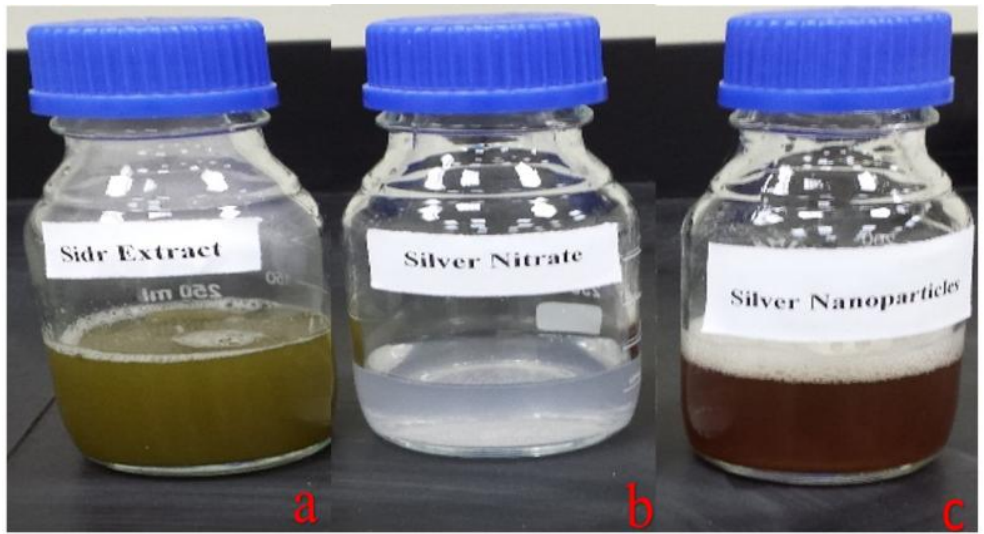

Figure 2:(a) sidr leaves extract; (b) $1 \mathrm{mM}$ silver nitrate; (c) silver nanoparticles

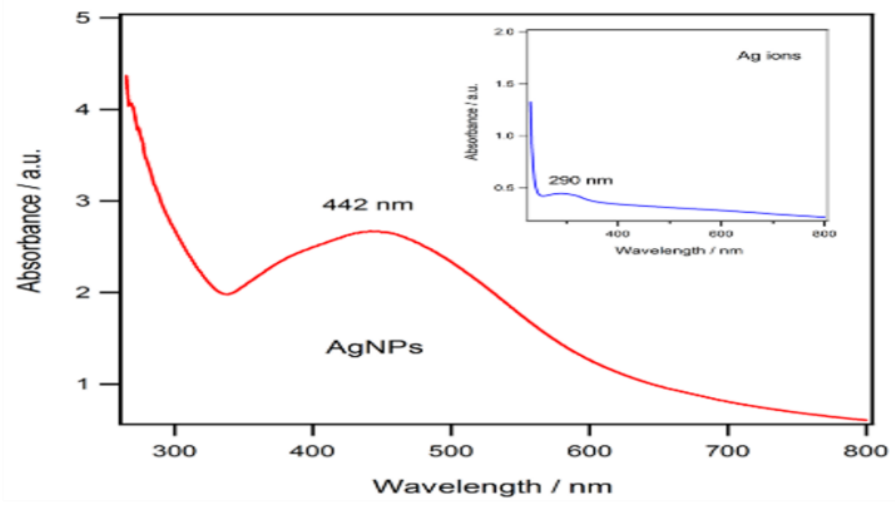

Figure 3: UV-vis spectra of AgNPs synthesized by sidr leaves extract. The inset shows the absorbance spectrum measured for $\mathrm{Ag}$ ions before the bio-reduction process. 


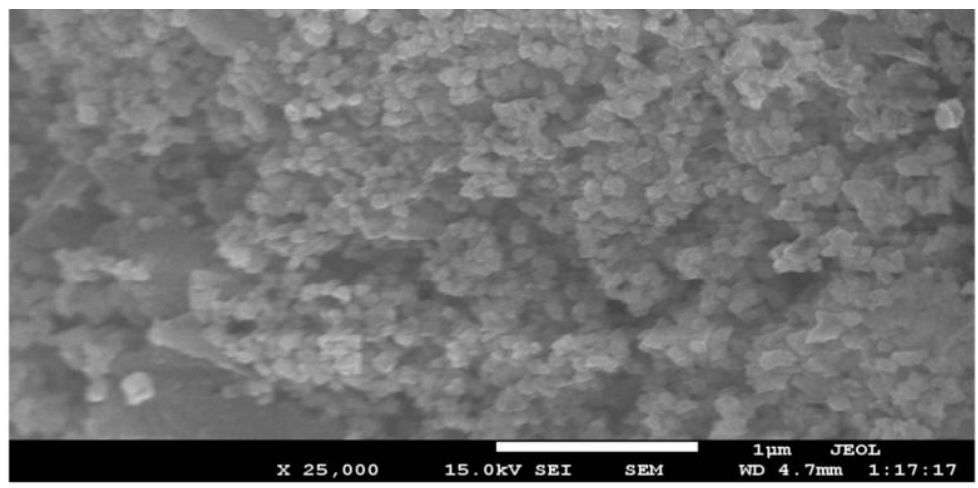

Figure 4: FE-SEM image of silver nanoparticles synthesized by sidr leaves extract

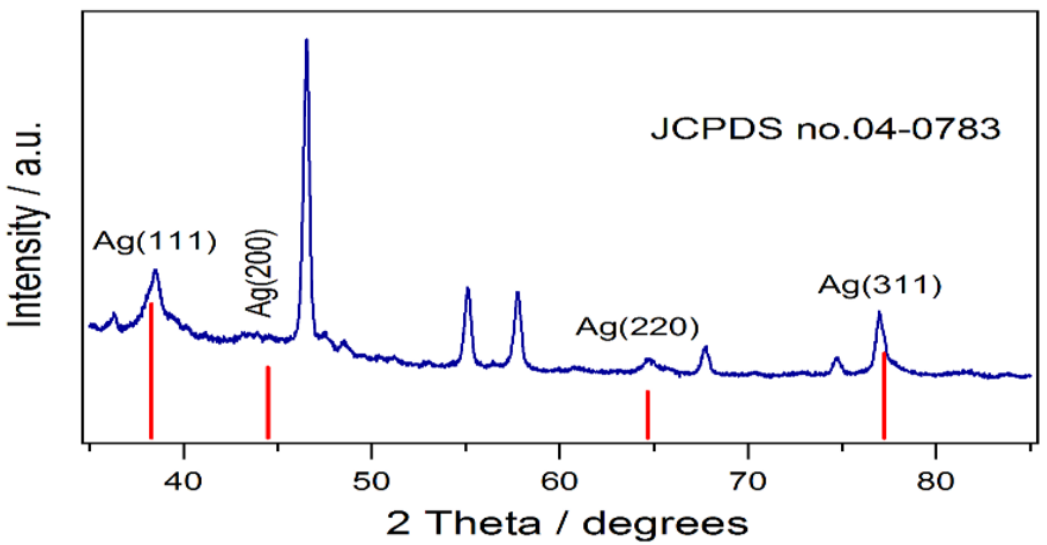

Figure 5: XRD pattern of as-synthesized AgNPs

In the present investigation, silver nanoparticles inhibited the growth of all gram positive and gram-negative bacteria and exerted the highest growth inhibitory effects compared to sidr leaves extract and 1 $\mathrm{mM}$ silver nitrate. $K$. pneumoniae was the most sensitive microorganism to silver nanoparticles with IZD $15.67 \pm 0.33$. Our findings agree with other observations (Okafor et al., 2013; Prasad and Swamy, 2013). Silver nanoparticles exert efficient growth inhibitory effect due to their extremely large surface area, which provides better contact with microorganisms. The nanoparticles release silver ions in the bacterial cells, which enhance their antibacterial activity (Morones et al., 2005; Muthukrishnan et al., 2015). Bactericidal activity of silver nanoparticles are influenced by the particles size, the smaller the particles, the greater the antibacterial efficacy. This suggests that the AgNPs may penetrate inside the bacteria causing damage by interacting with electron phosphorous and sulphur containing compounds such as DNA (Baker et al., 2005). The synthesized silver nanoparticles exhibited significant antibacterial effect on both Gram classes of bacteria (Kora et al., 2010; Rhim et al., 2013). Inhibition zones of Amikacin antibiotic discs were in between $29.00 \pm 0.00$ $\mathrm{mm}$ for Strept. Pyogenes and $22.00 \pm 0.00$ $\mathrm{mm}$ for $K$. pneumoniae.The statistical analysis revealed that there were significant differences in the values $(\mathrm{P} \leq 0.05)$ for silver nitrate and silver nanoparticles among the investigated organisms. No significant differences in the values $(\mathrm{P} \leq 0.05)$ were observed for sidr leaves extract and amikacin $(30 \mu \mathrm{g})$ on bacteria. 
In conclusion, this study concluded that sidr leaves extract was successfully used for synthesis of silver nanoparticles and it can be used for synthesis of metal nanoparticles in nanotechnology industry. Formation of silver nanoparticles was confirmed using UV-Vis Spectrophotometer, FE-SEM and XRD analysis. Silver nanoparticles inhibited the growth of gram positive and gramnegative bacteria and $K$. pneumoniae was the most sensitive organism. Preparation of nanoparticles drugs as effective antimicrobials synthesized by plant extract being simple, fast, eco-friendly, low cost and presented the ideal attitude for treatment of bacterial infection and limitation of drug resistance.

\section{Competing Interest}

The authors declare that they have no competing interests.

\section{Funding and Policy}

This study was sponsored by Deanship of scientific research, Najran University, Kingdom of Saudi Arabia (Grant Code: NU/ESCI/14/010).

\section{Acknowledgment}

The authors thank Najran University, Saudi Arabia for its financial support of this study. Special thank for Prof. FaridHarraz for helping and advising during confirmation of silver nanoparticles synthesis. The authors are thankful to prof. Mohammed Ammar for helping in data statistical analysis.

\section{References}

Ajitha, B., Ashok, K.R.Y., Sreedhara, R.P. 2015. Biosynthesis of silver nanoparticles using Momordica charantia leaf broth: Evaluation of their innate antimicrobial and catalytic activities. J. Photochem. Photobiol. B: Biol., 146: 1-9.

Baker, C., Pradhan, A., Pakstis, L., Pochan, D.J., Shah, S.I. 2005. Synthesis and antibacterial properties of silver nanoparticles. J. NanoSci. Nanotechnol., 5: 24-9.

Bhuvaneswaria, T., Thiyagarajana, M., Geethab, N., Venkatachalam, P. 2014. Bioactive compound loaded stable silver nanoparticle synthesis frommicrowave irradiated aqueous extracellular leaf extracts of Naringicrenulata and its wound healing activity in experimental rat model. ActaTropica, 135: 55-61.

Dhand, V., Soumya, L., Bharadwaj, S., Chakra, S., Bhatt, D., Sreedhar, B. 2016. Green synthesis of silver nanoparticles using Coffeaarabica seed extract and its antibacterial activity. Materials Sci. Engi., 58: 36-43.

El-Kamali, H.H., Mahjoub, S.A. 2009. Antibacterial Activity of Francoeuria crispa, Pulicaria undulata, Ziziphus spina-christi and Cucurbitapepo against Seven Standard Pathogenic Bacteria. Ethnobotanical Leaflets, 13: 722-33.

Gouda, H.A., Masoud, E.A., 2014.In vitro antibacterial and synergistic effects of some plant extracts against Staphylococcus aureus and Klebsiella pneumoniae. J. Antimicrob. Photon, 129: 338-346.

Ibrahim, H.M.M. 2015. Green synthesis and characterization of silver nanoparticles using banana peel extract and their antimicrobial activity against representative microorganisms. J. Radiation Res. Appl. Sci., 8: 265-275.

Jeeva, K., Thiyagarajan, M., Elangovan, V., Geetha, N., Venkatachalam, P. 2014. Caesalpinia coriaria leaf extracts 
mediated biosynthesis of metallicsilver nanoparticles and their antibacterial activity against clinicallyisolated pathogens. Industrial Crops and Products, 52: 714-720.

Judita, P., Irena, M., Dovile, J., Joana, S. 2014. Antimicrobial activity of silver nanoparticles synthesized using plant extracts. Vet. Med. Zoot. T., 65(87): 61-67.

Kaur, G., Verma, R.K., Rai, D.K., Rai, S.B $2012 . \quad$ Plasmon-enhanced luminescence of Sm complex using silver nanoparticles in polyvinyl alcohol. J. Lumin, 132: 1683-1687.

Koneman, E.W., Allen, S.D., Janda, W.M., Schreckenberger, P.C., Winn, W.C. 1992. Packaged in Kit Identification System. Color Atlas and Textbook of Diagnostic Microbiology. Koneman, E.W. (Eds.), 4th Edn. B. Lippincott Co., Philadelphia, PA163-170.

Kora, A.J., Sashidhar, R.B., Arunachalam, J. 2010. Gum kondagogu (Cochlospermum gossypium): A template for the green synthesis and stabilization of silver nanoparticles with antibacterial application. Carbohydrate Polymers, 82: 670679.

Koyyati, R., Nagati, V.B., Nalvothula, R., Merugu, R., Kudle, K.R., Marx, P., Padigya, P.M. 2014. Antibacterial activity of silver nanoparticles synthesized using Amaranthus viridis twig extract. Int. J. Res. Pharm. Sci., 5(1): 32-39.

Lalitha, A., Subbaiya, R., Ponmurugan, P. 2013. Green synthesis of silver nanoparticles from leaf extract Azhadirachta indica and to study its anti-bacterial and antioxidant property. Int. J. Curr. Microbiol., 2(6): 228-235.

Latha, M., Sumathi, M., Manikandan, R.,
Arumugam, A., Prabhu, N.M. 2015. Biocatalytic and antibacterial visualization of green synthesized silver nanoparticles using Hemidesmus indicus. Microbial Pathogenesis, 82: 43-49.

Leela, A., Vivekanandan, M. 2008. Tapping the unexploited plant resources for the synthesis of silver nanoparticles. African J. Biotechnol., 7(17): 31623165.

Levy, S.B., Marshall, B. 2004. Antibacterial resistance worldwide: causes, challenges and responses. Nat. Med., 10: $122-129$.

Lia, D., Liua, Z., Yuana, Y., Liub, Y., Niu, F. 2015. Green synthesis of gallic acid-coated silver nanoparticles with high antimicrobial activity and low cytotoxicity to normal cells. Process Biochem., 50: 357-366.

Mandal, S., Pal, N.K., Chowdhury, I.H., Deb Mandal, M. 2009. Antibacterial activity of ciprofloxacin and trimethoprim alone and in combination against Vibrio cholerae O1 biotype El Tor serotype Ogawa isolates. Polish J. Microbiol., 58: 57-60.

Morones, J.R., Elechiguerra, J.L., Camacho, A., Ramirez, J.T. 2005. The bactericidal effect of silver nanoparticles. Nanotechnol., 16: 2346-2353.

Muhammad, A., Farooq, A., Muhammad Ramzan, S.A.J., Muhammad, A.I., Umer, R. 2012. Green Synthesis of Silver Nanoparticles through Reduction with Solanum xanthocarpum L. Berry Extract: Characterization, Antimicrobial and Urease Inhibitory Activities against Helicobacter pylori. Int. J. Mol. Sci., 13: 992-994.

Muniyappan, N., Nagarajan, N.S. 2014. Green synthesis of silver 
nanoparticles with Dalbergia spinosa leaves and their applications in biological and catalytic activities. Process Biochem., 49: 1054-1061.

Muthukrishnan, S., Bhakya, S., Senthil Kumar, T., Rao, M.V. 2015. Biosynthesis, characterization and antibacterial effect of plant-mediated silver nanoparticles using Ceropegiath waitesii - Anendemic species. Industrial Crops and Products, 63: 119-124.

Najah, A.M. 2012. Antibacterial activity of Silver Nanoparticles Using Stem bark of Juglansregia against Streptococcus mutans, Streptococcus sanguis and Porphyromonas gingivalis. MDJ, 2(9): 184-189.

Nazif, N.M. 2002. Phytoconstituents of Zizyphus spina-christi L. Fruits and their antimicrobial activity. Food Chem., 76: 77-81.

NCCLS. 1993. Performance standards for antimicrobial disc susceptibility tests. Approved standard NCCLS publication M2-A5, Villanova, PA, USA.

Okafor, F., Janen, A., Kukhtareva, T., Edwards, V., Curley, M. 2013. Green Synthesis of Silver Nanoparticles, Their Characterization, Application and Antibacterial Activity. Int. J. Environ. Res. Public Health, 10: 5221-5238.

Prasad, R.R., Swamy, V.S. 2013. Antibacterial Activity of Silver Nanoparticles Synthesized by Bark Extract of Syzygium cumini. J. Nanoparticles, Article ID 431218, 6 pages.

Rajakumar, G., Abdul Rahuman, A. 2011. Larvicidal activity of synthesized silver nanoparticles using Ecliptaprostrata leaf extract against filariasis and malaria vectors. Acta
Tropica, 118: 196-203.

Reiad, N.A., Abdel Salam, O.E., Abadir, E.F., Harraz, F.A. 2013. Green synthesis of antibacterial chitosan films loaded with silver nanoparticles. Chinese J. Polymer Sci., 31(7): 984-993.

Remya, R.R., RadhikaRajasree, S.R., Aranganathan, L., Suman, T.Y. 2015. An investigation on cytotoxic effect of bioactive AgNPs synthesized using Cassia fistula flower extract on breast cancer cell MCF-7. Biotechnol. Reports, 8: 110115.

Rhim, J.W., Wang, L.F., Hong, S.I. 2013. Preparation and characterization of agar/silver nanoparticles composite films with antimicrobial activity. Food Hydrocolloids, 33: 327-335.

Salem, W.M., Haridy, M., Sayed, W.F., Hassan, N.H. 2014. Antibacterial activity of silver nanoparticles synthesized from latex and leaf extract of Ficussycomorus. Industrial Crops and Products, 62: 228-234.

Sathya, A., Ambikapathy, V. 2012. Studies on the Phytochemistry, Antimicrobial activity and green synthesis of nanoparticles using Cassia toraL. Drug Invent Today, 4(8): 408-410.

Satyavani, K., Gurudeeban, S., Ramanathan, T., Balasubramanian, T. 2013. Ipomoea pes-caprae Mediated Silver Nanoparticles and their Antibacterial Effect. Sci. Int., 1: 155-159.

Savithramma, N., Linga, R.M., Rukmini, K., Suvarnalatha, D.P. 2011. Antimicrobial activity of silver nanoparticles synthesized by using medicinal plants. Int. J. Pharma. Chem. Res., 3: 1394-1402.

Shahat, A.A., Pieters, L., Apers, S., Nazeif, N.M., Abdel-Azim, N.S., Berghe, D.V., Vlietinck, A.J. 2001.Chemical 
and biological investigations on Zizyphus spina-christi L. Phytother. Res., 15(7): 593-597.

Sukirtha, R., Priyanka, K.M., Antony, J.J., Kamalakannan, S., Thangam, R., Gunasekaran, P., Krishnan, M., Achiraman, M. 2011. Cytotoxic effect of green synthesized silver nanoparticles using Melia azedarach against in vitro hela cell lines and lymphoma mice model. Process Biochem., 47: 273-279.

Sundararajan, B., Kumari, B.D.R. 2014. Biosynthesis of Silver Nanoparticles in Lagerstroemia Speciosa (L.) Pers and their Antimicrobial Activities.
Int. J. Pharm. Pharm. Sci., 6(3): 3034.

Veerasamy, R., Zi, X.T., Gunasagaran, S., Wei Xiang, T.F., Chou Yang, E.F., Jeyakumar, N., Arumugam Dhanaraj, S. 2011. Biosynthesis of silver nanoparticles using Mangosteen leaf extract and evaluation of their antimicrobial activities. J. Chem. Soc., 15: 113120.

Venugopal, N., Mitra, A. 2013. Influence of temperature dependent morphology on localized surface plasmon resonance in ultra-thin silver island films. Appl. Surf. Sci., 85: 357-372.

\section{How to cite this article:}

Masoud E. A., A. Al-Hajry M and Al-Marrani. A. 2016. Antibacterial Activity of Silver Nanoparticles Synthesized By Sidr (Ziziphus spina- Christi) Leaf Extract against Pathogenic Bacteria. Int.J.Curr.Microbiol.App.Sci. 5(4): 226-236. doi: http://dx.doi.org/10.20546/ijcmas.2016.504.028 